\title{
The institutional environment and the number of bank relationships: an empirical analysis of European SMEs
}

\author{
Ginés Hernández-Cánovas · Johanna Koëter-Kant
}

Accepted: 26 August 2008/Published online: 27 September 2008

(C) The Author(s) 2008. This article is published with open access at Springerlink.com

\begin{abstract}
This article examines the association between creditor protection, as measured by the nature of legal rules and the quality of law enforcement, and multiple bank relationships using a unique survey sample of SMEs from 19 European countries. We find that the likelihood of multiple banking is the highest for SMEs in French-civil-law countries, next highest for German-civil-law countries, and the lowest in Scandinavian-civil-law and Englishcommon-law countries. We also find that SMEs in countries with low legal efficiency are more likely to establish multiple bank relationships. These results seems to confirm the underlying idea in the law and finance literature that relevant loan risk for banks also arises from low quality of laws and institutions and not just from firm-specific characteristics. Banks in countries where protection of creditor rights is poor may resort to multiple banking to share this additional risk. Policy makers can use our findings to justify the necessity of improving their institutions by reducing legal formalisms and thereby, lowering the enforcement costs in the courts. This would lead to better loan contracting and enhance the flow of debt capital, which is required for a healthy and dynamic economy.
\end{abstract}

G. Hernández-Cánovas

Technical University of Cartagena, Murcia, Spain

J. Koëter-Kant $(\square)$

VU University Amsterdam, Amsterdam,

the Netherlands

e-mail: jkoeter@feweb.vu.nl
Keywords Creditor rights - SMEs $\cdot$ Bank relationships · Legal environment · Financial systems

JEL Classifications $\mathrm{G} 21 \cdot \mathrm{G} 32 \cdot \mathrm{L} 26$

\section{Introduction}

A topic that receives considerable attention in the financial intermediation literature is the existence of multiple bank relationships. Financial intermediation theory suggests that the ability of banks and firms to benefit from the use of private information determines whether single or multiple banking prevails. This is especially true for SMEs, which are, compared to large firms, informationally more opaque and, therefore, are more prone to the advantages and disadvantages of proprietary information that flows into an exclusive bank relationship (Diamond 1984; Ramakrishnan and Thakor 1984; Boyd and Prescott 1986; Petersen and Rajan 1994).

Many researchers have tried to explain observed differences in the number of bank relationships at the firm level, but more recent studies suggest that firms and banks may also use the number of bank relationships to mitigate a country's legal and institutional constraints. The existence of a link between a country's financial system and its institutional environment first appeared in the finance and law literature (La Porta et al. 1997, 1998; Levine 1998). These studies indicate that relevant loan risk for banks arises not 
only from the firm's credit worthiness, but also from the quality of laws and institutions in the environment the bank operates in. In a legal system with rules that strongly protect the rights of creditors and mechanisms that rigorously enforce the law, lenders can more easily control borrower risk and reduce the expected loss in the event of default. However, in countries with weak protection of creditor rights, lenders have to resort to contracting tools that do not rely on laws or institutions, such as diffuse ownership of loans. There are some recent studies attempting to explain the observed difference in the number of bank relationships, but a comprehensive analysis specifically examining the impact of cross-country variation in the number of bank relationships for European SMEs is to our knowledge not available yet. ${ }^{1}$

Our article attempts to fill this void by analyzing a unique sample of 4,959 SMEs from 19 European countries. The use of such a broad sample allows us to examine if country-specific determinants influence the firm-bank relationship beyond firm-specific factors. We begin our analysis by testing if cross-country differences are significant in explaining variation in multiple banking. Consistent with our conjecture we find that 12 out of 18 country dummies are significant at the $1 \%$ level. We then examine the effect of the country's legal origin on multiple bank relationships for SMEs. We find that firms in French-civil-law countries are more likely to maintain several bank relationships than firms operating under Germancivil-law, while single banking seems to be more likely for firms in English-common-law and Scandinavian-civil-law countries. However, we still find additional variation in the number of bank relationships that cannot be explained by legal origin alone.

To further analyze this, we next examine several country-specific determinants of multiple banking, specifically, those factors that reflect the protection of creditor rights, proxied by laws and the efficiency of institutions enforcing these laws. Our results indicate that SMEs in countries with inefficient loan enforcement mechanisms and strong protection of creditor

\footnotetext{
1 Ongena and Smith (2000) report that differences in the legal and the financial environment across countries explain some of the variation in the number of bank relationships for large firms, while Detragiache et al. (2000) show that the likelihood of multiple banking for Italian SMEs depends on loan enforcement mechanisms and fragility of banks.
}

rights are more likely to maintain multiple bank relationships, showing that banks use multiple banking as a non-price mechanism to control for countryspecific risk. We also show that the association between multiple banking and bank fragility is non-monotonous. An increase in bank fragility reduces the likelihood of multiple bank relationships for firms operating in stable banking systems. SMEs operating in fragile banking systems are more likely to maintain multiple bank relationships as bank fragility increases. Financial environment also seems to have a significant impact on whether SMEs maintain one or multiple bank relationships. The likelihood of multiple bank relationships increases for SMEs operating in countries where the banking system is more developed and concentrated and where capital markets are smaller and less active.

The above results show that part of the relationship between the bank and the firm is also shaped by country-specific characteristics, mainly by factors linked to the quality of laws and institutions related to protecting creditor rights.

The article proceeds as follows. Section 2 discusses previous research and develops the hypotheses. Section 3 presents the data and method. Section 4 presents the results, and Section 5 concludes.

\section{Theory and hypotheses development}

In Europe, we observe large cross-country variation in the number of bank relationships established by small firms. Although, some of this variation might be explained in terms of demand and risk factors linked to firm-specific characteristics, the law and finance literature suggests that differences in legal systems across countries might also influence the number of bank relationships per firm. ${ }^{2}$ The underlying idea, pioneered by La Porta et al. $(1997,1998)$

\footnotetext{
$\overline{2}$ Much of the early financial intermediation theory assumes that the choice between single and multiple bank relationships depends to a large extent on the ability of firms and banks to benefit from the use of private information that flows into an exclusive bank relationship. The lender has monopoly access to proprietary information about the borrower (Kane and Malkiel 1965), which reduces the ability of the firm to change banks (Greenbaum et al. 1989) and enables the lender to extract monopoly rents (Sharpe 1990). The firm, in turn, may benefit from enhanced access to debt capital (Petersen and Rajan 1994; Berger and Udell 1995) and increased flexibility (Boot and Thakor 1994).
} 
and Levine (1998), is that loan contracts are more efficient in countries where the environment is more tailored to writing and enforcing financial contracts. This in contrast to environments where banks have to deal with additional risk, beyond the firm level, arising from low quality of laws and institutions.

In a legal system with rules that strongly protect the rights of creditors and mechanisms that rigorously enforce the law, lenders can more easily control borrower risk and reduce the expected loss in the event of default. In such an environment single banking, which is more cost efficient than multiple banking (Diamond 1984; Ramakrishnan and Thakor 1984; Boyd and Prescott 1986), should dominate. However, to reduce borrower risk in countries with weak protection of creditor rights, lenders resort to contracting tools that do not rely on laws or institutions, such as diffuse ownership of loans. ${ }^{3}$ Multiple banking helps to reduce this risk in two ways. First, by increasing the degree of diversification loan risk is shared by more banks and second, by increasing the ex post cost of debt restructuring the incentive for borrowers to default strategically is reduced (Bolton and Scharfstein 1996). ${ }^{4}$

La Porta et al. (1998) show that variation in creditor protection across countries can be explained in terms of cross-country differences in legal origin. They find that creditor rights are the least emphasized in French-civil-law countries and that their legal systems are the weakest in enforcing contracts. They also show that common-law countries enhance creditor rights the most, while countries with German and Scandinavian legal traditions have the most efficient enforcing mechanisms. We conjecture that the likelihood of multiple banking relationships is the highest

\footnotetext{
3 Diamond (2004) shows that shorter-term loans with more diffuse ownership make it easier for lenders to enforce contracts, especially in countries with inefficient enforcement mechanisms and poor protection of creditor rights.

${ }^{4}$ Multiple banking may also serve banks to increase their bargaining power. According to Ergungor (2004), firms cannot commit themselves to not exploit the lender and banks cannot trust courts for a fair solution of the conflict when creditor rights are poor. To enforce contracts without court intervention banks can credibly threaten the borrower with withholding valuables services such as loans and credits. In doing so a bank prefers the involvement of other lenders in the firm thereby reducing the soft budget constraint and making the threat of withholding the funds more credible.
}

for firms in countries with French legal heritage, where protection of creditor rights is the weakest.

The influence of legal and institutional differences on non-price terms of loan contracts has received considerable attention for large firms (DemirgüçKunt and Maksimovic 1998, 1999; Ongena and Smith 2000; Esty and Megginson 2003; Bancel and Mittoo 2004; Qian and Strahan 2007). ${ }^{5}$ Regarding determinants of loan contracts for small firms, a number of contributions suggest, however, that law and institutional factors are even more important for small firms than for large firms (Holmstrom and Tirole 1997; Hall et al. 2004; Jõeveer 2005). We are only aware of one paper examining the association between multiple banking and loan enforcement mechanisms for SMEs. This paper, by Detragiache et al. (2000), shows that weak loan enforcement mechanisms increase the likelihood of multiple banking for Italian SMEs. Our study adds to the literature of bank relationships by analyzing the effect of a country's legal system on multiple banking for a sample of 4,959 SMEs from 19 European countries. In the next section, we present our data and method.

\section{Data and method}

\subsection{Data}

To create our initial sample we utilize several data sources. First, country-level information is obtained from the Conference on Bank Concentration and Competition, La Porta et al. (1998), Demirgüç-Kunt and Levine (1999), and Ongena and Smith (2000).

\footnotetext{
5 Demirgüç-Kunt and Maksimovic (1998, 1999) report that short-term financing is more frequently used by publicly traded firms in countries where the legal system is inefficient or costly to use, while Ongena and Smith (2000) show that differences in the legal environment across countries explain some of the variation observed in the number of bank relationships. Esty and Megginson (2003) find that lenders in countries with weak protection of rights and unreliable legal enforcement mechanisms create larger and more diffuse syndicates to deter strategic default. Bancel and Mittoo (2004) report that factors related to debt are influenced more by the country's institutional structure than those related to equity. Results provided by Qian and Strahan (2007) show that under weak creditor protection, banks loans are associated with more diffused ownership and shorter maturities.
} 
Second, firm-specific variables are obtained from the 2002 ENSR survey on small and medium-sized enterprises, Observatory of European SMEs, provided by the EIM Business and Policy Research in The Netherlands. ${ }^{6}$ From the 7,669 checked and approved interviews that are available in the ENSR Survey 2002, we selected the 4,959 observations that contain information about the number of banking relationships of the individual firms. In Table 1 we provide the distribution of the sample by country and sector. The number of firms per country ranges from 88 in Liechtenstein to 583 in Italy. As for the nine activity sectors considered in the survey, the lowest representation corresponds to the Repair and Hotels/ Catering industries with 114 and 236 observations, respectively, whereas 891 and 753 firms belong to the Manufacturing and Construction industries, respectively.

\subsection{Method}

In this section, we present the variables and the model we use to analyze the effect of country-specific characteristics on the one versus multiple banking decision.

\subsubsection{The dependent variable}

To create the dependent variable we utilize the ENSR Survey in which managers are asked the number of banks they have credit lines with. The answers are categorized as follows: (a) only one bank, (b) two or three banks, and (c) four banks or more. Using these answers we build a dummy

\footnotetext{
${ }^{6}$ The 2002 ENSR Survey on SMEs uses a computer-assisted telephone interviewing (CATI) system to collect data from entrepreneurs and managers within SMEs, all being independent private enterprises with less than 250 employees in all sectors of industry in Europe. The survey was conducted from April-August 2001. To arrive at sufficiently reliable conclusions at the level of size classes within individual countries more than 100 interviews for each size class-country combination were carried out, finally resulting in 7,699 completed interviews. The overall design and implementation of the stratification, the questionnaire, and the fieldwork were done in close collaboration between staff from EIM Business and Policy Research in the Netherlands, partners in the ENSR network and Intromart. See http://europa.eu.int/comm/ enterprise/enterprise_policy/analysis/observatory_en.htm for further information.
}

variable, multiple, which is given a value of one when the number of bank relationships is higher than one and zero otherwise.

Table 2 gives an overview of the number of bank relationships by country and firm size ranked in ascending order. Panel A of Table 2 shows that firms in North European countries, such as Denmark, Great Britain, and The Netherlands, among others, have, on average, fewer bank relationships than firms in countries such as Spain, Portugal, and Italy. For example, $79 \%$ of the firms in the UK maintain only one bank relationship, while $21 \%$ uses two or three banks, and only $0.5 \%$ deals with four or more banks. This in contrast to Spain where only $22 \%$ has one bank relationship compared to $40 \%$ with two or three bank relationships, and $37 \%$ with four or more. Panel $\mathrm{B}$ shows the number of bank relationships by firm size. Less than $6 \%$ of micro and small firms are involved with more than three banks, while for medium size firms this is more than $19 \%$. Overall, the cross country patterns observed in our SME sample seem to be rather consistent with the patterns observed by Ongena and Smith (2000) in a sample of large firms.

\subsubsection{The independent variables}

In this section, we describe the explanatory variables utilized in our posterior analysis of multiple banking. We do so by classifying the variables into countryand firm-specific characteristics. Table 3 provides detailed definitions of all the variables.

Country-specific characteristics. The variables in this section represent the country-specific characteristics that influence the supply and terms of credit that lenders are willing to provide to borrowers. We consider two sets of country-specific variables. The first set includes the variables creditor rights, rule of law and legal efficiency, which account for differences across countries in legal protection of creditor rights and quality of enforcement mechanisms. Though we consider these variables the most important determining factors of multiple banking, we also include a second set of country-specific variables, such as commercial banking concentration, private credit, trade and capitalization, to control for unmeasured variation in credit supply.

The variable creditor rights tabulate scores using two default strategies, being liquidation and 


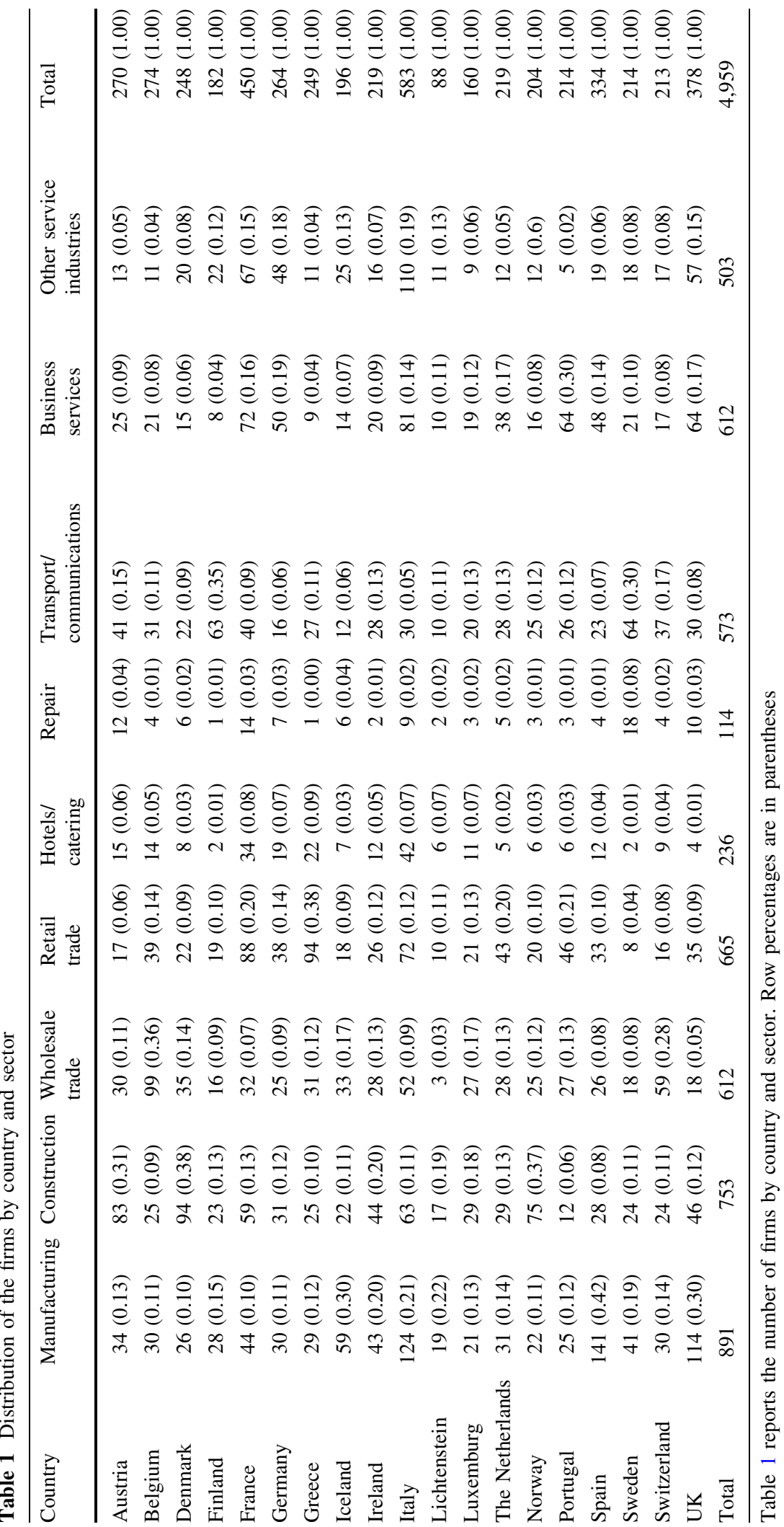


Table 2 Overview of number of bank relationships by country and firm size ranked in ascending order

\begin{tabular}{|c|c|c|c|c|c|}
\hline Country & $N$ & Average & $\begin{array}{l}\text { One bank } \\
\text { relationship }\end{array}$ & $\begin{array}{l}\text { Two or three } \\
\text { bank relationships }\end{array}$ & $\begin{array}{l}\text { Four or more bank } \\
\text { relationships }\end{array}$ \\
\hline \multicolumn{6}{|c|}{ Panel A. Number of bank relationships by country ranked in ascending order } \\
\hline Denmark & 248 & 1.2056 & 198 & 49 & 1 \\
\hline UK & 378 & 1.2169 & 298 & 78 & 2 \\
\hline The Netherlands & 219 & 1.2511 & 166 & 51 & 2 \\
\hline Norway & 204 & 1.2696 & 154 & 45 & 5 \\
\hline Sweden & 214 & 1.3271 & 149 & 60 & 5 \\
\hline Finland & 182 & 1.3846 & 116 & 62 & 4 \\
\hline Iceland & 196 & 1.449 & 114 & 76 & 6 \\
\hline Ireland & 219 & 1.4977 & 125 & 79 & 15 \\
\hline France & 450 & 1.5578 & 223 & 203 & 24 \\
\hline Lichtenstein & 88 & 1.5909 & 43 & 38 & 7 \\
\hline Germany & 264 & 1.6439 & 111 & 136 & 17 \\
\hline Switzerland & 213 & 1.6526 & 90 & 107 & 16 \\
\hline Austria & 270 & 1.7296 & 94 & 155 & 21 \\
\hline Luxemburg & 160 & 1.7375 & 65 & 72 & 23 \\
\hline Belgium & 274 & 1.7445 & 98 & 148 & 28 \\
\hline Greece & 249 & 1.8514 & 75 & 136 & 38 \\
\hline Italy & 583 & 1.8954 & 164 & 316 & 103 \\
\hline Portugal & 214 & 1.9766 & 54 & 111 & 49 \\
\hline Spain & 334 & 2.1527 & 74 & 135 & 125 \\
\hline Total & 4,959 & & 2,411 & 2,057 & 491 \\
\hline \multicolumn{6}{|c|}{ Panel B. Number of bank relationships by firm size ranked in ascending order } \\
\hline \multicolumn{6}{|c|}{ Number of employees } \\
\hline $0-9$ & 2,454 & 1.5122 & 1,340 & 971 & 143 \\
\hline $10-49$ & 1,392 & 1.6128 & 671 & 589 & 132 \\
\hline $50-249$ & 1,113 & 1.8347 & 400 & 497 & 216 \\
\hline Total & 4,959 & & 2,411 & 2,057 & 491 \\
\hline
\end{tabular}

Table 2 gives an overview of the number of firm-bank relationships by country and firm size ranked in ascending order. Data are obtained from the 2002 ENSR survey on small and medium-sized enterprises, observatory of European SMEs, provided by the EIM Business and Policy Research in The Netherlands

reorganization. The index ranges from 0 to 4 , with higher values indicating the existence of more creditor rights. ${ }^{7}$ The variable rule of law is an assessment of the law and order tradition in the country provided by the International Country Risk (ICR) Agency. This index ranges from 0 to 10, where low levels of the score denote less reliance on the legal system to mediate disputes. In the same spirit of Ongena and Smith (2000) we create an interaction variable creditor rights $*$ rule of law to take into account that real creditor protection not only depends

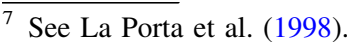

on laws, but also on their enforcement as well. High quality of legal system enforcement could substitute for weak rules, because active and well-functioning courts can step in and rescue investors abused by firm management. Legal efficiency is an index produced by the country risk rating agency Business International Corporation. This is an assessment of the efficiency and integrity of the legal environment as it affects business and ranges from zero to 10, with lower scores indicating lower efficiency levels. We expect the sign for the variables creditor rights * rule of law and legal efficiency to be negative, because for banks the benefits of multiple bank relationships 
Table 3 Description of variables and data sources

\begin{tabular}{l} 
Variable name \\
\hline Dependent variable \\
Exclusivity $^{\mathrm{a}}$ \\
Country and industry dummies \\
Industry dummies $^{\mathrm{a}}$
\end{tabular}

Country dummies

Firm-specific characteristics

Size $^{\mathrm{a}}$

Age $^{\mathrm{a}}$

Soft information ${ }^{\mathrm{a}}$

Hard information $^{\mathrm{a}}$

Country-specific characteristics

Bank fragility ${ }^{\mathrm{b}}$

Commercial banking concentration ${ }^{\mathrm{c}}$

Private credit ${ }^{\mathrm{d}}$

Trade $^{\mathrm{d}}$

Capitalization $^{\mathrm{d}}$

Legal efficiency ${ }^{\mathrm{e}}$

Creditor rights ${ }^{\mathrm{e}}$
Description and source

Dummy variable that takes on the value one when the firm has credit lines with more than one bank and zero otherwise

Nine industry dummies indicating the firm main activity. Each variable takes on the value one if the firm belongs to one of the following sectors: Manufacturing, Construction, Wholesale Trade, Retail Trade, Hotels and Catering, Repair, Transport and

Communications, Business Services, and Other Service Industries; and zero otherwise

Nineteen country dummies

An indicator of the firm size, which takes on the values: 1 when the firm has less than 9 employees, 2 when the number of employees is between 10 and 49, and 3 when the number of employees is between 50 and 250

A measure of the number of years that the firm has been in operation, which takes on the values: 1 when it has been less than 2 years, 2 when it has been between 2 and 5 years, 3 when it has been between 5 and 10 years, and 4 when it has been more than 10 years

Dummy variable that takes on the value one when the bank obtains only qualitative (soft) information from the firm and zero when it gets hard information: (1) Balance Sheet and Profit and Loss statement, (2) budget for next year(s), (3) financial plan and cash flow forecast, and (4) information on unpaid invoices; or both kinds of information.

Dummy variable that takes on the value one when the bank only obtains hard information from the firm: (1) Balance Sheet and Profit and Loss statement, (2) budget for next year(s), (3) financial plan and cash flow forecast, and (4) information on unpaid invoices; and zero when it gets soft information or both types of information

A measure of the fragility of a country's banking system, measured as the average credit rating of tracked banks within a country. It ranges from 0 to 10 , with lower scores implying less bank default risk

A measure of the degree of concentration of the banking sector, calculated as the fraction of assets held by the three largest commercial banks in the country, averaged over the period 1995-1999

A measure of the financial intermediary development, calculated as claims on the private sector by the deposit money banks to GDP average over the period 1990-1997

A measure of capital markets activity, calculated as the value of the trades of domestic equities on domestic exchanges divided by GDP average over the period 1990-1997

A measure of capital markets size, calculated as the ratio of the value of domestic equities traded on domestic exchanges to GDP average over the period 1990-1997

An assessment of the efficiency and integrity of the legal environment as it affects business, particularly foreign firms, averaged over the period 1980-1983. It is produced by the country risk rating agency Business International Corporation and it may be taken to represent investors' assessments of conditions in the country in question. The index ranges from zero to 10, with higher values indicating higher efficiency levels

An indicator of the protection of creditor rights, calculated by adding one for each of the following conditions that the country's bankruptcy law satisfies: (i) the country imposes restrictions, such as creditors' consent or minimum dividends to file for reorganization; (ii) secured creditors are able to gain possession of their security once the reorganization petition has been approved (no automatic stay); (iii) secured creditors are ranked first in the distribution of the proceeds that result from the disposition of the assets of a bankrupt firm; and (iv) the debtor does not retain the administration of its property pending the resolution of the reorganization. The index ranges from zero to four, with higher values indicating the existence of more creditor rights 
Table 3 continued

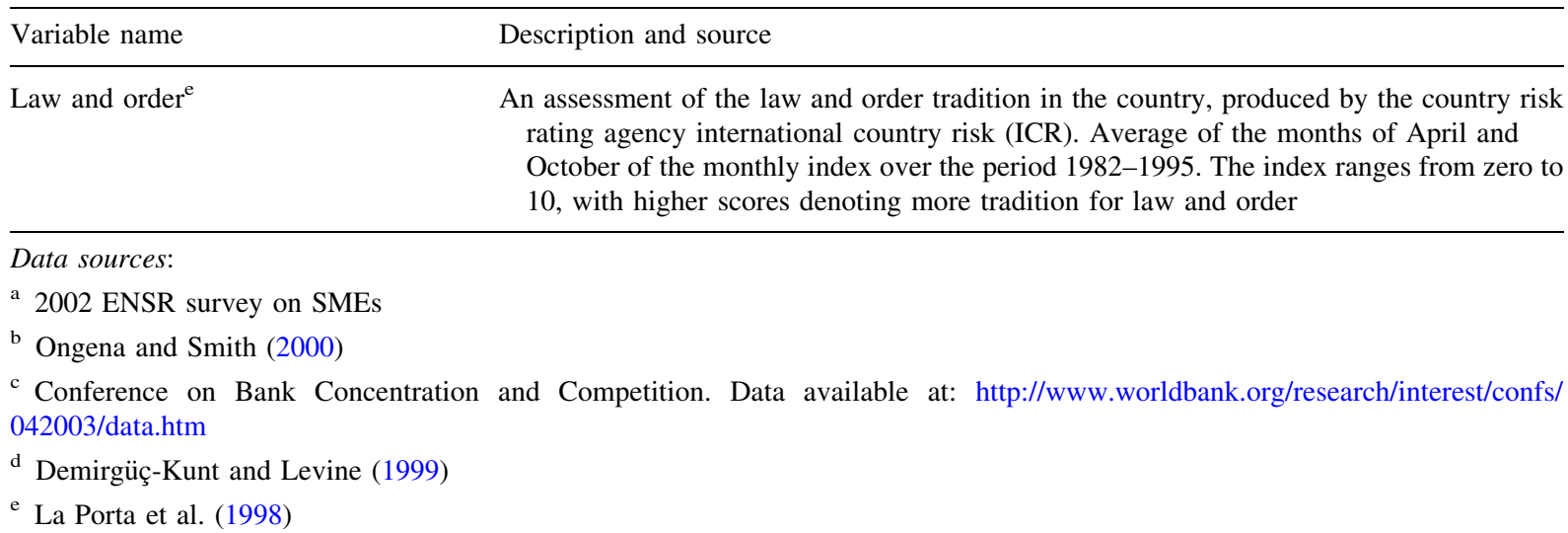

decrease when the efficiency of the legal system and the protection of creditor rights increase.

To ensure that the above institutional variables really reflect differences in credit supply across countries due only to variations in legal systems, we control for unmeasured variation in credit supply using several factors related with a country's financial system. The variable bank fragility is the average credit rating across banks rated within a country and defined as a range between 0 and 10, with lower values corresponding to less default risk. In stable banking systems banks are more likely to withhold a loan due to low quality of the borrower than because of liquidity restrictions from the side of the bank, increasing the proportion of low quality firms looking to refinance their projects. Then, as the banking system becomes more stable we expect that firms will have better access to additional funding from relationship banks than to new loans from other lenders, thereby increasing the likelihood of multiple banking. Commercial banking concentration is proxied by the fraction of bank assets held by the three largest commercial banks in each country. In concentrated banking systems, reduced inter-bank competition decreases the ability of firms to raise debt capital from non-relationship banks, increasing the likelihood of multiple banking. The degree of development of the banking system in a country is measured with the variable private credit, which is defined as claims on the private sector by deposit money banks to GDP. We measure market activity with the variable trade, which is the value of the trades of domestic equities on domestic exchanges divided by GDP, whereas the variable capitalization, which equals the ratio of the value of domestic equities traded on domestic exchanges to GDP, proxies for market size. If securities market and bank loan financing are alternative sources of funding, one would expect that firms in countries with better developed capital markets (banking systems) are less (more) likely to establish multiple bank relationships. Table 4 gives an overview of the variables by country.

Firm-specific characteristics. We account for the heterogeneity across firms including several firmspecific control variables in our model ${ }^{8}$ Empirical evidence shows that firm size, age, and activity sector are important determinants of the number of bank relationships. ${ }^{9}$ To proxy for firm size we use the number of employees working in the firm. This variable is coded from 1 to 3 , where 1 represents firms with 0-9 employees, 2 are firms with 10-49 employees, and 3 are firms with 50-249 employees, or what we respectively call micro, small, and medium firms. The variable age reflects the number of years that the firm has been in operation. It ranges from 1 to 4 , with 1 being less than 2 years in operation, 2 representing $2-5$ years, 3 being 510 years, and 4 more than 10 years in operation. Finally, we include nine sector dummies to control for differences across industries.

\footnotetext{
$\overline{8}$ In the construction of our firm-specific dummy variables we are limited by the answer categories as used in the ENSR survey.

9 See Detragiache et al. (2000), Degryse and Ongena (2001) and Hernández-Cánovas and Martínez-Solano (2005) among others.
} 
Table 4 Country-specific characteristics

\begin{tabular}{|c|c|c|c|c|c|c|c|c|}
\hline & $\begin{array}{l}\text { Creditor } \\
\text { rights }\end{array}$ & $\begin{array}{l}\text { Law and } \\
\text { order }\end{array}$ & $\begin{array}{l}\text { Legal } \\
\text { efficiency }\end{array}$ & $\begin{array}{l}\text { Private } \\
\text { credit }\end{array}$ & $\begin{array}{l}\text { Commercial banking } \\
\text { concentration }\end{array}$ & $\begin{array}{l}\text { Bank } \\
\text { fragility }\end{array}$ & Capitalization & Trade \\
\hline Austria & 3 & 10 & 9.5 & 0.93 & 0.44 & 3.90 & 0.12 & 0.08 \\
\hline Belgium & 2 & 10 & 9.5 & 0.56 & 0.75 & 4.50 & 0.36 & 0.05 \\
\hline Denmark & 3 & 10 & 10 & 0.38 & 0.71 & 5.25 & 0.34 & 0.16 \\
\hline Finland & 1 & 10 & 10 & 0.77 & 0.75 & 6.21 & 0.29 & 0.12 \\
\hline France & 0 & 8.98 & 8 & 0.89 & 0.33 & 4.63 & 0.33 & 0.17 \\
\hline Germany & 3 & 9.23 & 9 & 0.94 & 0.32 & 2.23 & 0.24 & 0.28 \\
\hline Greece & 1 & 6.18 & 7 & 0.18 & 0.71 & 9.00 & 0.15 & 0.06 \\
\hline Iceland & - & - & - & - & 0.87 & - & - & - \\
\hline Ireland & 1 & 7.8 & 8.75 & 0.29 & 0.68 & 4.43 & 0.26 & 0.14 \\
\hline Italy & 2 & 8.33 & 6.75 & 0.52 & 0.30 & 5.77 & 0.17 & 0.08 \\
\hline Liechtenstein & - & - & - & - & - & - & - & - \\
\hline Luxembourg & - & - & - & - & 0.21 & 3.17 & 0.69 & 0.43 \\
\hline The Netherlands & 2 & 10 & 10 & 0.90 & 0.81 & 5.89 & 0.26 & 0.14 \\
\hline Norway & 2 & 10 & 10 & 0.57 & 0.61 & 5.47 & 0.13 & 0.05 \\
\hline Portugal & 1 & 8.68 & 5.5 & 0.54 & 0.46 & 4.75 & 0.30 & 0.23 \\
\hline Spain & 2 & 7.8 & 6.25 & 0.69 & 0.54 & 5.70 & 0.62 & 0.33 \\
\hline Sweden & 2 & 10 & 10 & 0.46 & 0.78 & 4.27 & 0.98 & 0.76 \\
\hline Switzerland & 1 & 10 & 10 & 1.65 & 0.77 & 2.63 & 1.13 & 0.55 \\
\hline UK & 4 & 8.57 & 10 & 1.14 & 0.47 & 3.17 & 0.69 & 0.43 \\
\hline
\end{tabular}

Table 4 gives an overview of country-specific characteristics. See Table 3 for an exact variable description

We also include a dummy variable to proxy for the flow of information inside the firm-bank relationship. Berger et al. (2001) distinguish two kinds of information flows. On the one hand, firms can give hard information, which is easily observable, verifiable, and transmittable data. On the other hand, banks can also obtain soft information, which is gathered by interaction between the loan officer and the firm's manager and refers to the manager's capabilities, integrity, and the quality of firm projects. This kind of information appears to be very important in relationship lending, since small businesses usually are lacking reliable hard information. From the ENSR survey we obtain what type of information the firms regularly present to their bank(s). We create three dummy variables, one if the firm only presents soft information, one if the firm only presents hard information and one when the firm provides both soft and hard information. We use the variable 'both' as our base category in the analysis. As shown by Von Rheinbaben and Ruckes (2004), firms shape their relationship with banks using two dimensions: the number of creditors and the amount of confidential information given to the creditors. Firms that disclose a substantial amount of private information are more likely to work with a small number of creditors in order to restrict the dissemination of confidential information, whereas firms disclosing little private information are less worried to deal with many lenders. We therefore expect a negative association between the flow of soft information and the likelihood of having multiple bank relationships and a positive association for firms that only provide hard information.

Table 5 describes the information in possession of banks by country and size. The majority of firms (85\%) provide their bank(s) with some form of balance sheet and/or income statement. Other forms of information disclosure are less common for SMEs. Surprisingly, 306 out of 4,959 firms (6\%) do not provide information at all to their bank(s). The release of soft information ranges from $68 \%$ in Norway to $2 \%$ and $6 \%$ in France and Italy, respectively, which seems consistent with the argument of Von Rheinbaben and Ruckes (2004). 
Table 5 Overview of information provided by SMEs to banks by country and size

\begin{tabular}{llllll}
\hline Country & $N$ & Balance/income & Budget & Pro-forma & Inventory Unpaid invoices $\begin{array}{l}\text { Qualitative } \\
\text { (soft info) }\end{array}$
\end{tabular}

Panel A. Information in possession of banks by country

\begin{tabular}{|c|c|c|c|c|c|c|c|}
\hline Austria & 270 & 261 & 75 & 86 & 49 & 106 & 69 \\
\hline Belgium & 274 & 256 & 69 & 75 & 55 & 63 & 43 \\
\hline Denmark & 248 & 224 & 95 & 48 & 24 & 21 & 23 \\
\hline Finland & 182 & 165 & 20 & 20 & 13 & 6 & 34 \\
\hline France & 450 & 415 & 41 & 28 & 8 & 7 & 7 \\
\hline Germany & 264 & 248 & 22 & 25 & 14 & 23 & 26 \\
\hline Greece & 249 & 242 & 62 & 57 & 56 & 20 & 50 \\
\hline Iceland & 196 & 178 & 65 & 31 & 49 & 44 & 17 \\
\hline Ireland & 219 & 182 & 65 & 81 & 29 & 35 & 26 \\
\hline Italy & 583 & 508 & 91 & 44 & 21 & 57 & 33 \\
\hline Liechtenstein & 88 & 77 & 21 & 14 & 10 & 17 & 13 \\
\hline Luxembourg & 160 & 134 & 21 & 16 & 4 & 11 & 16 \\
\hline The Netherlands & 219 & 196 & 59 & 56 & 42 & 84 & 24 \\
\hline Norway & 204 & 91 & 51 & 40 & 43 & 25 & 130 \\
\hline Portugal & 214 & 201 & 20 & 21 & 14 & 24 & 16 \\
\hline Spain & 334 & 240 & 36 & 29 & 14 & 14 & 39 \\
\hline Sweden & 214 & 180 & 93 & 75 & 52 & 32 & 50 \\
\hline Switzerland & 213 & 198 & 59 & 43 & 26 & 29 & 21 \\
\hline UK & 378 & 311 & 98 & 104 & 58 & 59 & 57 \\
\hline Total & 4,959 & 4,307 & 1,063 & 893 & 581 & 677 & 694 \\
\hline \multicolumn{8}{|c|}{ Panel B. Information in possession of banks by firm size } \\
\hline \multicolumn{8}{|c|}{ Number of employees } \\
\hline $0-9$ & 2,454 & 2,126 & 365 & 283 & 210 & 263 & 260 \\
\hline $10-49$ & 1,392 & 1,233 & 335 & 293 & 192 & 220 & 208 \\
\hline $50-249$ & 1,113 & 948 & 363 & 317 & 179 & 194 & 226 \\
\hline Total & 4,959 & 4,307 & 1,063 & 893 & 581 & 677 & 694 \\
\hline
\end{tabular}

Table 5 gives an overview of the information SMEs provide to their banks by country and firm size ranked in ascending order. Data are obtained from the 2002 ENSR survey on small and medium-sized enterprises, observatory of European SMEs, provided by the EIM Business and Policy Research in The Netherlands

\subsubsection{The model}

To examine the impact of country-specific characteristics on the likelihood of multiple banking we estimate logistic regressions in the following form:

Multiple $_{i}=\Phi\left(\alpha+\beta_{1} \mathrm{CSV}_{i}+\beta_{2} \mathrm{FSC}_{i}+\varepsilon_{i}\right)$

where Multiple $_{i}$ is the dummy variable indicating whether the $i$ th firm maintains one or multiple bank relationships; $\mathrm{CSV}_{i}$ is a vector of country-specific variables; $\mathrm{FSC}_{i}$ represents the set of firm-specific control characteristics; and $\varepsilon_{i}$ is the residual.

\section{Results}

\subsection{Firm-level regressions}

In model 1, Table 6, we first analyze the existence of differences across firms in the number of bank relationships by regressing the variable multiple on firm size and age, and the flow of information. Consistent with our expectations and most of the empirical evidence for SMEs, we find that larger and older firms are more likely to maintain multiple bank relationships. Large firms are more complex, have higher financing needs. and require more variety of 
Table 6 Logistic regressions of single versus multiple bank relationships on firm level variables and country dummies

\begin{tabular}{|c|c|c|c|}
\hline & (1) & (2) & (3) \\
\hline Constant & $-1.0642 * * *(0.1759)$ & $-1.0966 * * *(0.1960)$ & $-3.2863 * * *(0.2905)$ \\
\hline \multicolumn{4}{|l|}{ Firm-specific characteristics } \\
\hline Size & $0.3562 * * *(0.0373)$ & $0.3399 * * *(0.0381)$ & $0.5591 * * *(0.0451)$ \\
\hline Age & $0.1051 * * *(0.0411)$ & $0.1086 * * *(0.0415)$ & $0.2030 * * *(0.0477)$ \\
\hline Hard information & $0.1733 * 0.1009$ & $0.1627(0.1018)$ & $0.0953(0.1191)$ \\
\hline Soft information & $-0.2112 * *(0.0851)$ & $-0.2043 * *(0.0858)$ & $0.0448(0.0996)$ \\
\hline \multicolumn{4}{|l|}{ Industry dummies } \\
\hline Manufacturing industry & & $0.2210 *(0.1137)$ & $0.1961(0.1293)$ \\
\hline Construction & & $-0.3149 * * *(0.1176)$ & $-0.0992(0.1334)$ \\
\hline Wholesale trade & & $0.3482 * * *(0.1232)$ & $0.3720 * * *(0.1390)$ \\
\hline Retail trade & & $0.0378(0.1198)$ & $-0.0791(0.1351)$ \\
\hline Hotels/catering & & $-0.0834(0.1602)$ & $-0.3689 * *(0.1748)$ \\
\hline Repair & & $-0.1360(0.2112)$ & $0.1292(0.2361)$ \\
\hline Transport/communications & & $0.1312(0.1247)$ & $0.3811 * * *(0.1414)$ \\
\hline Business services & & $0.0717(0.1223)$ & $0.0503(0.1373)$ \\
\hline \multicolumn{4}{|l|}{ Country dummies } \\
\hline Austria & & & $1.9431 * * *(0.2123)$ \\
\hline Belgium & & & $1.8182 * * *(0.2116)$ \\
\hline Denmark & & & $-0.1691(0.2317)$ \\
\hline Finland & & & $0.4976 * *(0.2295)$ \\
\hline France & & & $1.5906 * * *(0.1946)$ \\
\hline Germany & & & $1.9564 * * *(0.2118)$ \\
\hline Greece & & & $2.3395 * * *(0.2199)$ \\
\hline Iceland & & & $1.1201 * * *(0.2236)$ \\
\hline Ireland & & & $0.9559(0.2156)$ \\
\hline Italy & & & $2.6700 * * *(0.1944)$ \\
\hline Lichtenstein & & & $1.6118 * * *(0.2767)$ \\
\hline Luxembourg & & & $1.8212 * * *(0.2344)$ \\
\hline Norway & & & $0.0493(0.2440)$ \\
\hline Portugal & & & $2.4441 * * *(0.2315)$ \\
\hline Spain & & & $2.8429 * * *(0.2179)$ \\
\hline Sweden & & & $0.2539(0.2252)$ \\
\hline Switzerland & & & $1.4900 * * *(0.2188)$ \\
\hline UK & & & $0.1676(0.2112)$ \\
\hline Observations & 4,959 & 4,959 & 4,959 \\
\hline Adjusted- $R^{2}$ & 0.033 & 0.045 & 0.257 \\
\hline
\end{tabular}

$*, * *, * * *$ Significant at the $10 \%, 5 \%, 1 \%$ level

financial services, explaining why they allocate their banking business across multiple financial intermediaries. In addition, establishing bank relationships takes time, which explains the positive association between age and multiple banking. As predicted by Von Rheinbaben and Ruckes (2004), we find that SMEs that provide only hard information are more likely to have more banking relationships than firms who provide both, soft and hard information, while firms only providing soft information are more likely to maintain a single bank relationship to restrict the disclosure of confidential information.

In model 2 we include the eight industry dummies, leaving out other services industries, which we use as 
our base category. Manufacturing and Wholesale Trade (Construction) have positive (negative) and statistically significant coefficients, indicating that firms in those sector of activity are more (less) likely to maintain multiple bank relationships than businesses belonging to the sector of other service industries. The results for the firm-specific variables remain qualitatively the same.

In model 3 , we add the 18 country dummies to the firm-level characteristics. We don't include a dummy for The Netherlands, which we use as our base category. After including the country dummies the variable soft information becomes statistically insignificant. This suggests that the negative association between the flow of private information and the number of banks predicted by Von Rheinbaben and Ruckes (2004) is not orthogonal to cross-country heterogeneity. It might be that fear of information disclosure, which makes firms work with fewer banks, depends on the institutional environment of the country. It also should be notice that after including the country dummies, the coefficients of the industry dummies Manufacturing and Construction become insignificant, whereas those of Hotel/ Catering and Transport/Communications become significant with a negative and a positive sign respectively. This suggests that some cross country differences in multiple banking could be explained by industry specialization. In unreported descriptive statistics we find that firms operating in the construction sector have on average few bank relationships (57\% has one bank relationship compared to only $7 \%$ that have 4 or more). Table 1 reveals that construction is the dominant sector in Denmark and Norway which indeed belong to the countries that on average have the fewest bank relationships. In addition, the manufacturing sector has on average many bank relationships and is highly concentrated in Spain, the country with the most bank relationships as is shown in Table $2 .^{10}$

Inspection of model 3 also reveals that 12 out of 18 country dummies are statistically significant at the

\footnotetext{
${ }^{10}$ We also have run our models by industry, because certain countries might have a comparative advantage in a certain sector and therefore different capital requirements. This might influence the relationship with the lender(s). Although, there is some variation between industries our ultimate results remain the same. Results are available upon request.
}

$1 \%$ level. To confirm the existence of significant cross-country differences in multiple banking for SMEs, we test the hypothesis that all the country estimates are equal. The equality is rejected at the $1 \%$ level, which is consistent with the findings for large companies as reported by Ongena and Smith (2000), and with the expectations of Detragiache et al. (2000) for SMEs.

\subsection{Explaining cross-country variation}

The country dummy estimates in model 3 suggest that cross-country differences in the likelihood of multiple banking might be influenced by legal origin. ${ }^{11}$ Those countries with higher likelihood of multiple banking such as Austria, Belgium, France, Germany, Greece, Italy, Portugal, Spain and Switzerland are classified as French or German-civil-law countries, whereas most of the country estimates that are not significantly different from our base category are either English-common-law or Scandinaviancivil-law countries.

To test whether cross-country variation in multiple banking might be explained only in terms of legal origin we next test the equality of the country dummy estimates within legal origin groupings. We reject the equality at the $1 \%$ level for country dummy estimates inside the English-common-law and French-civil-law countries and at the 5\% level inside the German- and Scandinavian-civil-law countries, which suggest that there is additional variation in the number of bank relationships that cannot be explained by legal origin alone.

In model 1 of Table 7, we group the countries according to their legal origin and regress multiple on these four groups. We use German-civil-law as our reference group. ${ }^{12}$ Estimates of the firm-level

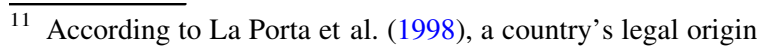
determines its commercial laws. Commercial laws basically come from two broad traditions: common law, which is English in origin, and civil law, which derives from Roman law. Within the civil tradition, commercial laws originate from three major families: French, German, and Scandinavian. In our sample, Ireland and United Kingdom are common-law countries; Belgium, France, Greece, Italy, The Netherlands, Portugal, and Spain are French-origin; Austria, Germany, and Switzerland are German-origin; Denmark, Finland, Norway, and Sweden are Scandinavian-origin.

12 Since Iceland, Lichtenstein, and Luxemburg are not classified, we leave these countries out of the analysis.
} 
Table 7 Logistic regressions of single versus multiple bank relationships on legal origin dummies and country-level variables

\begin{tabular}{|c|c|c|c|}
\hline & (1) & (2) & (3) \\
\hline Constant & $-1.4845 * * *(0.2401)$ & $1.8365 * * *(0.4173)$ & $2.5589 * * *(0.5050)$ \\
\hline \multicolumn{4}{|l|}{ Firm-specific characteristics } \\
\hline Size & $0.4988 * * *(0.0439)$ & $0.4912 * * *(0.0450)$ & $0.4979 * * *(0.0452)$ \\
\hline Age & $0.1258 * * *(0.0470)$ & $0.2107 * * *(0.0497)$ & $0.2076^{* * *}$ \\
\hline Hard information & $0.0994(0.1172)$ & $0.3184 * * *(0.1190)$ & (0.0497) $0.2842 * *$ \\
\hline Soft information & $0.0816(0.0978)$ & $-0.0020(0.0989)$ & $-0.010(0.0993)$ \\
\hline \multicolumn{4}{|l|}{ Industry dummies } \\
\hline Manufacturing industry & $0.3021 * *(0.1309)$ & $0.2374 *(0.1339)$ & $0.2441 *(0.1338)$ \\
\hline Construction & $-0.0512(0.1345)$ & $-0.1379(0.1360)$ & $-0.1219(0.1362)$ \\
\hline Wholesale trade & $0.3584 * *(0.1404)$ & $0.5263 * * *(0.1436)$ & $0.5349 * * *(0.1437)$ \\
\hline Retail trade & $-0.1841(0.1358)$ & $-0.0900(0.1384)$ & $-0.1236(0.1390)$ \\
\hline Hotels/catering & $-0.3311 *(0.1793)$ & $-0.2740(0.1814)$ & $-0.2909(0.1818)$ \\
\hline Repair & $-0.0057(0.2442)$ & $0.0422(0.2454)$ & $0.0559(0.2459)$ \\
\hline Transport/communications & $0.4163 * * *(0.1435)$ & $0.3674 * * *(0.1448)$ & $0.3789 * * *(0.1450)$ \\
\hline Business services & $0.0657(0.1380)$ & $0.0428(0.1418)$ & $0.0444(0.1415)$ \\
\hline \multicolumn{4}{|l|}{ Legal origin dummies } \\
\hline English-common law & $-0.9518 * * *(0.1153)$ & & \\
\hline French-civil law & $0.8152 * * *(0.0843)$ & & \\
\hline Scandinavian-civil law & $-1.2636^{* * *}(0.1070)$ & & \\
\hline \multicolumn{4}{|l|}{ Country-specific characteristics } \\
\hline Bank fragility & & $-0.0360(0.0358)$ & $-0.2337 * *(0.1123)$ \\
\hline Bank fragility $^{2}$ & & & $0.0240 * * *(0.0094)$ \\
\hline Legal efficiency & & $-0.6421 * * *(0.0434)$ & $-0.6440 * * *(0.0433)$ \\
\hline Creditor rights $*$ rule of law & & $0.0207 * * *(0.0041)$ & $0.0180 * * *(0.0045)$ \\
\hline Private credit & & $1.8875 * * *(0.2116)$ & $1.9492 * * *(0.2158)$ \\
\hline Commercial banking concentration & & $1.8618 * * *(0.2119)$ & $1.1210 * * *(0.3059)$ \\
\hline Trade & & $-0.8725(0.5507)$ & $-1.2693 * * *(0.5736)$ \\
\hline Capitalization & & $-1.3142 * * *(0.2955)$ & $-1.2152 * * *(0.2967)$ \\
\hline Observations & 4,515 & 4,515 & 4,515 \\
\hline Adjusted- $R^{2}$ & 0.214 & 0.238 & 0.239 \\
\hline
\end{tabular}

$*, * *, * * *$ Significant at the $10 \%, 5 \%, 1 \%$ level

variables remain unchanged, and the three legal origin dummies are statistically significant at the $1 \%$ level. Our evidence shows that the likelihood of multiple bank relationships is the highest for SMEs in French-civil-law countries, next highest in Germancivil-law countries, and the lowest in English-common-law and Scandinavian-civil-law countries. All pair-wise comparisons across legal origin groups are rejected at the $1 \%$ level, except for the equality between English common law and Scandinavian civil law, which is rejected at the $5 \%$ level.

The above evidence suggests that legal origin is a determining factor of multiple banking for SMEs, but it might not be the only one. To examine which country-specific characteristics may explain the multiple versus single banking decision, we replace the legal origin dummies by our country-level variables. The results are reported in Table 7, model 2 . Consistent with our expectations we find that the coefficient of the variable judicial efficiency is negative and statistically significant at the $1 \%$ level. This corroborates that banks use multiple banking as a non-price mechanism to control for additional risk in a country with low quality of enforcement mechanism. However, contrary to our expectations, the estimate on the variable creditor rights * rule of law is positive 
and significant at the $1 \%$ level. We would expect that multiple banking is more likely for firms in countries with low protection of creditor rights. Interestingly, Levine et al. (2000) reports a positive association between financial intermediary development and the protection and enforcement of creditor rights within a country, while our evidence indicates a positive association between multiple banking and the protection and enforcement of creditor rights. Given the result reported by Levine et al. (2000) and the evidence from our study, this might suggest that firms are more likely to engage in multiple bank relationships when the banking system is more developed.

The above explanation is also consistent with our finding of a positive association between multiple banking and the size of the banking sector. The coefficient of the variable private credit is positive and statistically significant at the $1 \%$ level. Additionally, we find a significant negative estimate on the variables trade and capitalization, which confirms the predicted substitution effect between securities market- and bank-financing. The likelihood of multiple banking increases with the size of the banking system and reduces with the size and activity of capital markets. Finally, the estimate on the variable commercial banking concentration is positive and significant $(\alpha=0.01)$. Reduced competition in a concentrated banking system decreases the ability of firms to raise debt capital from non-relationship banks, leading them to establish multiple bank relationships. ${ }^{13}$

In model 3, we include the squared value of the variable bank fragility to take into account potential non-monotonicities in the multiple banking decision. Detragiache et al. (2000) predict that the association

\footnotetext{
13 Baas and Schrooten (2006) suggest an alternative justification for this result. They state that the lack of verifiable information for SMEs can be compensated through relationship-based lending, which enables lenders to gathered information about the firm over time. However, relationshipbased lending may lead to relatively high interest rates, because the information collected by the bank is private. This effect is exponentially multiplied for firms borrowing from one bank because the information becomes exclusive, and for firms operating in a concentrated banking system due to reduced competition. Therefore, firms operating in a more concentrated banking system may use multiple banking as a diversification mechanism to reduce the ability of banks to take advantage of proprietary information.
}

between multiple banking and the fragility of the banking system has an inverse U-shape (increasing for low values of bank fragility and decreasing for relatively high values). However, we find that the coefficients of bank fragility and squared bank fragility are negative and positive, respectively, indicating the opposite association to the one reported by Detragiache et al. (2000). For firms in countries with stable banking systems, an increase in bank fragility reduces the likelihood of multiple banking, whereas those operating in fragile banking systems are more likely to maintain multiple bank relationships as bank fragility increases. Ongena and Smith (2000) observe a pattern similar to ours and justify the result by a desire of firms to diversify in highly fragile banking systems, while firms in stable banking systems consolidate services across banks as the system becomes more fragile. The coefficients of the other variables in the model remain qualitatively unchanged after the inclusion of bank fragility squared. ${ }^{14}$

\section{Conclusion}

This article examines the association between protection of creditors, as measured by the nature of legal rules and the quality of law enforcement, and the existence of multiple bank relationships in European small firms. Based on the law and finance literature we conjecture that banks use multiple banking as a non-price mechanism to reduce the loan risk arising from low quality of laws and institutions in the environment they operate in. This would explain the observed variation in the number of bank relationships per firm across European countries, in spite of the fact that the financial intermediation literature suggests that single banking is more cost efficient than multiple banking. More specifically, we examine the association between multiple banking and country-specific characteristics by analyzing those factors that reflect the protection of creditor rights, given by the laws and the efficiency of institutions enforcing these laws.

We perform our analyses using a unique survey sample of 4,959 SMEs from 19 European countries.

\footnotetext{
${ }_{14}$ Also note that the firm level control variables remain the same across all three models.
} 
Once we control for demand and risk factors linked to firm-specific characteristics, our results show that differences in enforcement costs and legal protection of creditors account for some variation in multiple banking across European countries. We find that multiple banking is more likely in countries with French civil-law tradition than in legal systems under German civil law. Single banking seems to be more likely for firms in countries with English common law and Scandinavian civil law heritage. This evidence indicates that legal systems with rules that rigorously protect creditor rights and efficient law enforcement mechanisms lead to single banking, hence, to better loan contracting and financial outcomes.

Next, we analyze which country-specific legal factors originate cross-country differences in multiple banking between and within legal origins. Our results show that SMEs in countries with low legal efficiency and strong protection of creditor rights are more likely to establish multiple bank relationships. This confirms that banks use diffuse ownership of loans as a non-price mechanism to control country risk induced by low quality of law enforcement mechanisms. The positive association between multiple banking and creditor rights seems to be the result of the financial system's structure. Countries with stronger protection of creditor rights have better developed banking systems which channel most of the financial resources to investment opportunities. This leads firms to establish more bank relationships. However, multiple banking might be less common in countries where securities market financing can be used as alternative funding, when bank loans are not available. Supporting this argument we find that multiple banking is more likely for firms operating in countries with larger banking systems, whereas single banking is more likely in countries where securities markets are larger and more active.

Our results also show that the association between multiple banking and the fragility of the banking system has a U-shape (decreasing for low values of bank fragility and increasing for relatively high values). This indicates that firms in stable banking systems consolidate services across banks as the system becomes more fragile, while they use multiple banking as a diversification mechanism in highly fragile banking systems. The same diversification argument may explain the positive association that we find between a country's concentration of the banking system and the likelihood of multiple banking. In fragile and concentrated banking systems, where refinancing from non-relationship banks might be difficult if the lender does not roll over the loan, a firm is more likely to establish multiple bank relationships to increase the probability that at least one relationship bank will refinance the project. The underlying logic in the diversification argument, as put forth by Detragiache et al. (2000), is that relationship banks are, compared to non-relationship banks, more predisposed to refinance the firm because they have a competitive advantage obtained from the proprietary information gathered during the relationship. However, Basel II requires banks to use standardized credit scoring models, which raises the question if the use of private information is still crucial for banks, and if multiple bank relationships as a diversification mechanism will remain important to firms. This opens an interesting area for future research.

The evidence presented in this article has clear implications for firms, banks, and policy makers. Firm owners seeking loans can use the results of this study to better understand the country-specific factors affecting the supply of credit that lenders are willing to provide and the conditions under which it is offered. They can also better manage the number of banks to be involved with. Banks have a responsibility and financial interest in facilitating the flow of capital to borrowers of small size. Banks can use our findings to help borrowers understand which factors (mainly quality of law and institutions) drive their decision when reducing the supply of credit. This might motivate firms to approach multiple bank lenders to fund their projects. Optimal loan contracting, which allows for an efficient flow of capital from providers to users of capital, is required for a healthy and dynamic economy. Policymakers can use these findings to justify the necessity of improving the institutions by reducing legal formalisms and thereby, lowering the enforcement costs in the courts.

Acknowledgments The permission of the EIM Business and Policy Research in The Netherlands to use the 2002 ENSR survey data and to publish findings based on analysis of that data is gratefully acknowledged. Responsibility for interpretation of the findings lies solely with the authors.

Open Access This article is distributed under the terms of the Creative Commons Attribution Noncommercial License which 
permits any noncommercial use, distribution, and reproduction in any medium, provided the original author(s) and source are credited.

\section{References}

Baas, T., \& Schrooten, M. (2006). Relationship banking and SMEs: A theoretical analysis. Small Business Economics, 27, 127-137.

Bancel, F., \& Mittoo, U. R. (2004). Cross-country determinants of capital structure choice: A survey of European firms. Financial Management, 33, 103-132.

Berger, A. N., Klapper, L. F., \& Udell, G. F. (2001). The ability of banks to lend to informationally opaque small businesses. Journal of Banking and Finance, 25, 21272167.

Berger, A. N., \& Udell, G. F. (1995). Relationship lending and lines of credit in small firm finance. Journal of Business, $68,351-381$.

Bolton, P., \& Scharfstein, D. S. (1996). Optimal debt structure and the number of creditors. Journal of Political Economy, 104, 1-25.

Boot, A. W. A., \& Thakor, A. V. (1994). Moral hazard and secured lending in an infinitely repeated credit market game. International Economic Review, 35, 899-920.

Boyd, J. H., \& Prescott, E. C. (1986). Financial intermediary coalitions. Journal of Economic Theory, 38, 211-232.

Degryse, H., \& Ongena, S. (2001). Bank relationships and firm profitability. Financial Management, Spring, 9-34.

Demirgüç-Kunt, A., \& Maksimovic, V. (1998). Law, finance, and firm growth. Journal of Finance, 53, 2107-2137.

Demirgüç-Kunt, A., \& Maksimovic, V. (1999). Institutions, financial markets, and firm debt maturity. Journal of Financial Economics, 54, 295-336.

Detragiache, E., Garella, P., \& Guiso, L. (2000). Multiple versus single banking relatioships: Theory and evidence. Journal of Finance, 55, 1133-1136.

Diamond, D. W. (1984). Financial intermediation and delegated monitoring. Review of Economics Studies, 51, 393414.

Diamond, D. W. (2004). Presidential address, committing to commit: Short-term debt when enforcement is costly. Journal of Finance, 59, 1447-1479.

Ergungor, O. E. (2004). Market- vs. bank-based financial systems: Do rights and regulations really matter? Journal of Banking and Finance, 28, 2869-2887.

Esty, B. C., \& Megginson, W. L. (2003). Creditor rights, enforcement, and debt ownership structure: evidence from the global syndicated loan market. Journal of Financial and Quantitative Analysis 38, 37-59.

Greenbaum, S., Kanatas, G., \& Venezia, I. (1989). Equilibrium loan pricing under the bank-client relationship. Journal of Banking and Finance, 13, 221-235.

Hall, G. C., Hutchinson, P. J., \& Michaelas, N. (2004). Determinants of capital structures of European SMEs. Journal of Business Finance and Accounting, 31, 711728.

Hernández-Cánovas, G., \& Martínez-Solano, P. (2005). Incidencia del número de relaciones bancarias en la financiación de la PYME y sus determinantes. Revista Española de Financiación y Contabilidad, 34, 13-44.

Holmstrom, B., \& Tirole, J. (1997). Financial intermediation, loanable funds, and the real sector. Quarterly Journal of Economics, 112, 663-691.

Jõeveer, K. (2005). What do we know about capital structure of small firms? EFMA 2005 Working Paper, Italy.

Kane, E. J., \& Malkiel, B. G. (1965). Bank portfolio allocation, deposit variability, and the availability doctrine. Quarterly Journal of Economics, 79, 257-261.

La Porta, R., López-de-Silanes, F., \& Shleifer, A. (1998). Law and finance. Journal of Political Economy, 106, 11131155.

La Porta, R., López-de-Silanes, F., Shleifer, A., \& Vishny, R. W. (1997). Legal determinants of external finance. Journal of Finance, 52, 1131-1150.

Levine, R. (1998). The legal environment, banks, and long-run economic growth. Journal of Money, Credit and Banking, 30, 596-613.

Levine, R., Loayza, N., \& Beck, T. (2000). Financial intermediation and growth: Causality and causes. Journal of monetary Economics, 46, 31-77.

Ongena, S., \& Smith, D. C. (2000). What determines the number of bank relationships? Cross-country evidence. Journal of Financial Intermediation, 9, 26-56.

Petersen, M. A., \& Rajan, R. G. (1994). The benefits of lending relationships: Evidence from small business data. Journal of Finance, 49, 3-37.

Qian, J., \& Strahan, P. E. (2007). How laws and institutions shape financial contracts: The case of bank loans. Journal of Finance, 62, 2803-2834.

Ramakrishnan, R. T. S., \& Thakor, A. V. (1984). Information reliability and a theory of financial intermediation. Review of Economic Studies, 51, 415-432.

Sharpe, S. (1990). Asymmetric information, bank lending, and implicit contracts: A stylized model of customer relationships. Journal of Finance, 45, 1069-1087.

Von Rheinbaben, J., \& Ruckes, M. (2004). The number and the closeness of bank relationships. Journal of Banking and Finance, 28, 1597-1615. 